\title{
Development of Job sheet-Aided Module in Children Clothing Courses Fashion Study Program off Universitas Negeri Medan
}

\author{
Hotmaria Tampubolon ${ }^{1}$, Surniati Chalid ${ }^{2}$, Ermidawati $^{3}$, Eka Rahma Dewi ${ }^{4}$ \\ \{tampubolonmaria0@gmail.com, ekarahma0107@gmail.com \} \\ Department of Family Welfare Education, Faculty of Engineering, Universitas Negeri Medan 1,2,3,4
}

\begin{abstract}
Children's Clothing courses encountered several obstacles in the learning process, among others namely, the material of children's clothing is an important part to understand. Learning with the use of media including the use of job sheets will make it easier in the learning process to be more effective. The results of the development of a jobsheet-assisted module both state the module and the job sheet are suitable for learning, but with some improvements. Student's limited test results state that modules and job sheets are acceptable for learning. Job sheet-assisted module field test results are also feasible to use, then the hypothesis shows that there is a difference in learning from applying a job sheetassisted module as a learning medium having a better success rate than those not using
\end{abstract}

Keywords: Module, job sheet, Children's Clothing

\section{Introduction}

The use of learning modules will greatly help the effectiveness of the learning process and the delivery of information. The presence of media in learning can also help increase student understanding, the presentation of data or information is more interesting and reliable, as well as facilitate the interpretation of data to obtain information. Lecturers or teachers are required to be able to understand, use the tools available in an effort to achieve the expected goals. For this reason, teachers must have sufficient knowledge and understanding of learning media. The learning media of this module is also compiled with the help of a children's clothing course job sheet.

In the children's clothing course there is still a module with the appropriate worksheet assisted, so that the learning process is carried out following the teaching to support the learning process. Therefore, the researchers tried to conduct research on the development of Worksheet-assisted modules in order to facilitate students in the learning process and learning that could run more effectively. The title of the research that was raised was "Development of Worksheet Assisted Assistance Modules in Children's Clothing Subjects in Medan Fashion University Study Program". 


\section{Research Method}

The research was conducted in the Fashion Study Program of the Family Welfare Education Department (PKK), Faculty of Engineering, Medan State University

The population and sample in this study were stambuk 2017, V semester students majoring in Fashion Study Program PKK. The sampling technique in this study was Nonprobability Sampling, namely the type of Purvosive Sampling, so that the sample in this study was all V semester students.

The main instruments used to collect data in this development are as follows:

a. Questionnaire Sheet Validation of Expert Team

The validation sheet is used to obtain assessment data from the validator about the product being developed, namely the module is divided into three, namely:

1. Validation sheet for subject matter experts.

2. Validation sheet for learning design experts.

3. Validation sheet for learning media experts.

b. Questionnaire sheet for student responses to the module. The questionnaire sheet, obtained from individual trials, small group trials and limited field trials. Grid of individual trial questionnaires, small group trials, and limited field trials

The development uses the development model of Borg \& Gall combined with the learning design model Dick \& Carey. The steps of the stages of development are as follows: (1) conducting preliminary research, which includes: (a) identification of learning needs or objectives and determining core competencies of subjects, (b) conducting learning analysis by determining more specific skills that must be studied, (c) identifying initial characteristics and behavior, and (d) writing core competencies and competency standards along with their indicators; (2) compile a benchmark reference test by developing an assessment item to measure the ability of students expected in the learning objectives; (3) collection of materials which include: (a) collection of learning materials, (b) making and collecting images (illustrations); (5) product validation; (6) product revisions; and (7) product testing.

The data obtained is data about the state of the module with jobsheet This data is collected through expert validation, questionnaires /questionnaires distributed to students. Assessment instruments for validators and individual trials, small groups and limited field groups.

\section{Result and Discussion}

Based on product assessment through a series of trials and revisions that have been made, this module with jobsheet is declared valid. The trial was conducted in six stages, namely: (1) material expert validation, (2) validation of learning design experts, (3) 
validation of learning media experts, (4) individual trials, (5) small group trials, and (6) limited field trials

The hypothesis proposed in this study is that produced between student learning outcomes learned with worksheet-assisted use modules and student learning outcomes that do not use worksheet-assisted modules. Testing the hypothesis used is a different test.

From the calculation results obtained because $t$ count $=25.08>\mathrm{t}$ table $=2.0105$, it was concluded that there were significant differences in student learning using worksheet-assisted modules with those not using

Table 1. Summary of Hypothesis Test Calculations

\begin{tabular}{lll}
\hline $\boldsymbol{t}_{\text {hitung }}$ & $\boldsymbol{t}_{\text {tabel }}$ & Conclusion \\
\hline 25.08 & 2,0105 & There is a difference \\
\hline
\end{tabular}

As a suggestion considering that during the learning process in schools still using modules in the form of textbooks only, it is recommended that also use more applicable modules that can help students understand learning material, and link learning obtained with students' real life so as to provide feedback better for students.

Considering that the conclusions in this study are still possible to be influenced by factors that have not been able to be controlled, it is still necessary to do further research on more and broader samples.

\section{Acknowledgements}

The author would like to thank to Directorate of Research and Community Service for the provision of research funds.

\section{References}

[1] Arsyad. Media Pembelajaran. Jakarta: PT. Raja Grafindo Permai. (2015)

[2] Arikunto. Dasar - Dasar Evaluasi Pendidikan. Jakarta: : PT. Rineka Cipta. (2013)

[3] Ernawati, \& Dkk. Modul Tata Busana Jilid 1. Klaten: PT. Macanan Jaya Cemerlang. (2008)

[4] Ermayanti.. Buku Ajar Tata Busana Jilid 2. Klaten: PT. Macanan Jaya Cemerlang. (2008)

[5] Muliawan. Menggambar Mode dan Menciptakan Busana Wanita. Jakarta: Gunung Mulia. (2002)

[6] Munadi. Media Pembelajaran Sebuah Pendekatan Baru. Jakarta: GP Press Group. (2013)

[7] Sanjaya. Penelitian Pendidikan Jenis, Metode dan Prosedur. Jakarta: KENCANA. (2013)

[8] Sugiyono. Metode Penelitian Pendidikan Kuantitatif, Kualitatif Dan R\&D. Bandung : Alfabeta. (2010) 
[9] Rohman. Panduan Menggambar Manusia menggunakan Media Pensil. Yogyakarta: C.V ANDI OFFSET. (2010)

[10] Poespo. Teknik Menggambar Mode Busana. Yogyakarta : Kanisius. (2000) 